\title{
Role of Governance in Employment Generation in Nigeria
}

\author{
${ }^{1}$ Danjuma Abdullahi MIPM, Phd, ${ }^{2}$ Bala Aliyu Kardi MNIM \\ ${ }^{1}$ College of law, governance and international studies Universiti Utara, Malaysia \\ ${ }^{2}$ Department of Public Administration Waziri Umaru Federal Polytechnic Birnin Kebbi Kebbi State Nigeria
}

\begin{abstract}
The purpose of this paper is to look into role of governance in employment generation in Nigeria because despite the efforts of government which aim at employment generation there is still many unemployed graduates roaming on the street constituting social malice to the country as a whole. The data was collected using descriptive approach, interview was also conducted with some of the employment generation agencies in order to gather empirical data. The findings revealed that unemployment in Nigeria has created tension and hatred between the haves and have not leading to communal clashes and the rise of such groups such as Boko Haram and Niger Delta militant, armed robbery, prostitution and child trafficking constituting hiccups to security of lives and properties. The paper recommends investment in education that will help in Skills development and training.
\end{abstract}

Keyword: Governance; Employment; Crises

\section{Introduction}

There is correlation between unemployment and poverty. The connection arises from the fact that growth will only translate to reduction of poverty if it is backed by creation of productive employment. In other word, improved employment and income opportunities for the poor is the principal route to reducing poverty. Throughout history, economic down-turn have always resulted in hardship and reduced quality of life for workers, employee, low income earners and vulnerable members of the society. The great depression of the 1930s resulted in dramatic socio-economic consequences not only in united states but world wide, there was sharp drop in national income, tax revenue, prices and profits, international trade plunged by two third, unemployment rose to $25 \%$ in the US and up to $35 \%$ in some countries, rural areas and farming experienced tough times as the prices of crops dropped by as much as $60 \%$ business collapsed and many people committed suicide.

The recent world economic crisis is not different from that of 1930 economic depression in term of impact. Unemployment is very high the most vulnerable groups affected by this are the youths, low skilled and immigrant workers. There was sharp drop in oil prices, decline in commodities prices, decline in export. Nigeria experienced decline in prices of oil which led to decline in revenue and virtually resulted to the crash of stock market. The slide in job figures deepened when the few industries that we inherited after Independence were mismanaged. Those that were created in the early years of military rule closed shop due to the profligacy of the Second Republic under President Shehu Shagari. That government was defined by the number of import licences given out to importers. Many indigenous manufacturing companies had to stop production because of the influx of foreign goods into the country. In the thick of military regimes, the harsh political environment and ill-conceived economic policies of successive governments led to massive capital flight. The Structural Adjustment Programme compounded the woes of manufacturers when the naira was devalued. Millions of youths were thrown into the job market. The situation never improved. Infrastructural decay, multiple taxes, brigandage and chaotic political milieu led many multinational companies to fold up. Perhaps, the major cause of unemployment in our country today is lack of electricity. Widespread epileptic power supply means that major companies have to spend huge sums of money generating their own energy for production and other operations.

Poor electricity supply has also had negative effects on small businesses. It is the reason why manufacturing companies could not produce to capacity; it is the reason why major companies had packed up and relocated to Ghana and other African countries in recent years. It is the reason why our youths continue to roam the streets. The situation in moribund textile industries across the country provides a sad example of how unemployment has deepened over the years. Textile companies used to be a major source of employment. For more than two decades, textile companies gradually shut down production because government promoted the importation of foreign fabrics. Hundreds of textile companies were forced to lay off workers when they could not compete with the influx of foreign fabrics. Millions of jobs were lost. Several attempts to reverse the policy have failed. Since the advent of democracy, all the policies that should have helped the economy and provide jobs for our youths have not been successful. The power problem has not improved; corruption is still very rife. It is one major reason why Nigerian youths suffer so much deprivation. Our financial institutions have shed 
more than 50, 000 jobs in the last five years. Corruption and poor management have hit the sector so hard and resulted in uncertainty. It has also resulted in the displacement of more than half of the employees that used to work in the Nigerian banking industry. At government level, all the agencies created for job provision have become tools for political patronage this and many others are some of the concern of the paper.

\section{Role of Governance in employment generation}

Nigerian is the third populous country in the world apart from China and India, economy is dominated by subsistence farmers, $60 \%$ of the population of Nigeria engages in agriculture, with $41 \%$ contribution to the GNP, despite the dominance of Agriculture oil sector contributes more than $80 \%$ of foreign exchange. Manufacturing sector contributes minimum of $3 \%$, while communication sector contribute $5.5 \%$ (National office of statistics 2010). According to CBN (2011) the living standard of those living in rural areas have worsened and some of the viable programmes of government that would enhance their living standard could not see the light of the day. Numerous programmes were put in place which aimed at reducing the rate of unemployment but all in vein without any impacts to the masses, for instance in 1976 when the Military government realized the negative consequence of unemployment as a result of the civil war came out with a programme known as operation feed the nation, by 1979 when the military handed over power to civilian government there was nothing to show as a tangible effects of the programme Apata, Igbalajobi, Awoniyi (2010) added that majority of poverty stricken people in Nigeria are rural populace that constitute $75 \%$ of the population due to lack of accessibility to micro -credit, poor education, lack of accessibility to agricultural extension workers and distance to market constitute hindrance to poverty eradication in Nigeria.

Like wise in 1981 when President Shagari came to power in his effort to further provide employment to thousand Nigerians came out with green revolution, just like its predecessor the green revolution also has it defect which led to importation of rice which affected the food security of the nation. Also as a result of the failure of Shagari government to addressed socio- economic problems that bedevil the nation that led to his over thrown in December 1983. By 1984 when the military came in to power unemployment was at the peak and the military government of that time also introduced back to land as a way of salvaging the country from crises, the programme also failed to addressed the problem of the youth. Other programmes introduced include The directorate of food, roads and rural infrastructure (DFFRI); National Directorate of employment (NDE); The establishment of peoples bank of Nigeria; Better life for rural women programme; The family support programme; Agric development programme, the nomadic and adult education programme. How ever in 1999 when the country returned to the democracy Poverty alleviation programme was launched in an attempt to provide youths with employment opportunities and later multiply in to National poverty eradication programme (NAPEP), other similar agencies introduced by the federal government include Nigerian economic empowerment and development strategies (NEEDS) and Millennium development goals Danjuma (2012).

Despites all these programmes the country is still bisect with the problem of poverty. According to National Office of Statistics (2012)revealed that 69.9\% in 2010 could not afford food, shelter and clothing, while in 2004 only 54.7\% could not afford. North East and North West recorded the highest prevalence with $77.7 \%$ and $76.3 \%$ respectively where the activities of Boko Haram sect are the worst heat. Sokoto and Niger state recorded the top list. Sanusi (2012) opined that Nigerian economy is dysfunctional as a results the poverty level in Nigeria will continue grow unless some thing is done to address the situation.

\section{Causes of unemployment in Nigeria}

Poor management of the economy: Our economy was badtardized by successive governments thereby living the masses in penury Ribadu (2012) attributed the problem to poor management, misuse of oil resources and corruption which has led to extinction of many industries of national relevance such as failure of Nigerian air ways, national shipping lines, steel rolling mills, car assembly plant which have created problem of inability of government to support a decent life and promising future for her citizens which led to bitter experience of terrorism.

Poor investment climate: That is failure of government to create enabling environment for the private sector to generate job opportunities.

Global economic crisis: Due to economic meltdown that is affecting the globe it created unemployment all over the globe especially in developing countries like Nigeria. It led to fluctuation of prices of oil in the global market as a result affected day to day running of government. NECA (2012) opined that invulnerable recurrent expenditure on huge cost of governance in sustaining government administration structures at the detriment of funding capital projects in vital sectors that would boost employment.

Wrong approach to employment creation: Also wrong policies of government in provision of employment contributed immensely to the unemployment crises in Nigeria. Low job statistics among youths have been around since the inception of bad economic management. Lack of accurate statistics on the number of people suffering from unemployment is also creating problem to nation. 
Poor infrastructure: Business growth and development in Nigeria is constraints by poor infrastructures such as good roads, poor electricity which resulted to the use of generator and the burden of generator is too high, lack of access to land, finance and services in which young job seekers could not provide. Youth are in disadvantage position especially access to all these facilities.

Access to entrepreneurial training such as tailoring, computer, incubation is been constraints by access to capital to establish their own after the training. Inadequate farming tools that could enhanced mechanized agriculture. Henrik (2006) cites in Onno (2011) assert that low opportunities for young graduates create problem of violence due to lack of job and idleness, because without job they will not be able play a useful role in the society

Table:1.1 Nigerian unemployment by age

\begin{tabular}{|l|l|l|l|}
\hline Age & 2009 & 2010 & 2011 \\
\hline $15-24$ & 33.5 & 38.2 & 37.7 \\
\hline $25-44$ & 16.3 & 24.1 & 22.4 \\
\hline $45-59$ & 12.5 & 19.6 & 18.0 \\
\hline $60-64$ & 17.8 & 22.1 & 21.4 \\
\hline
\end{tabular}

Adapted from Danjuma 2012

\section{Effects of unemployment in Nigeria}

The following are some of the effects of unemployment in Nigeria which include:-

Inequality of income is one of the effects of unemployment in Nigeria. The National Bureau of statistics opined that in $201065 \%$ of Nigeria's wealth is owned by $20 \%$ of the population, which manifest itself in so many dimensions such as concentration of wealth on the hands of few individuals while many are in abject poverty. Inequality of income, poverty and unemployment has led to increase in violent crimes in Nigeria. According to Hallary (2012) assert that the crisis in Nigeria was as a result of failure of governance to address socio-economic issues facing the nation.

According to the world investment report of UNCTAD. The economy witnessed declined in foreign direct investment from USD 8.65 billion in 2009 to USD 6.1 billion in 2010 due to activities of Boko Haram. Sanusi (2012) opined that Nigeria slower growth rate could be attributed to corruption and political obstacles associated with the removal of fuel subsidy.

Decline in quality of life which depend largely on family income, insecurity, tension and conflict.

Decline in access to shelter, education and health care, nutrition are drastically reduced which ultimately led to reduction in life span. NLC (2012) assert that bodied employment growth and improvement in the GDP had not transform into social well being, adding that unemployment had aggravated the spate of insecurity among other social vices in the polity

The tourism sector was also affected by the crisis in Nigeria. The sector is one of the employer of labour and fetched 80 billion annually but due to activities of Boko Haram, Niger Delta militant, kidnapping etc the sector was also in shamble.

Aviation industry has also witnessed low turnout of customers due to flight cancellation and air crash. The recent crash was that of Dana air crash that claimed more than one hundred and sixty lives (160).

In addition, unemployment resulted in increased in activities of Boko Haram and many other crimes going on in the affected areas especially the north-west and north east of Nigeria which resulted in closure of schools. In a place like Jos, People were divided along ethnic lines due to unemployment and poverty.

Table 1.2 Statistics of unemployment in Nigeria

\begin{tabular}{|l|l|l|}
\hline Unemployment & $\mathbf{2 0 1 0}$ & $\mathbf{2 0 1 1}$ \\
\hline Unemployment\% & 21.1 & 23.9 \\
\hline Population (Million) & 158.8 & 168 \\
\hline GDP Percentage & 1,224 & - \\
\hline Purchasing power & 2,160 & - \\
\hline \multicolumn{2}{|l|}{ Adapted from Nigeria 2011} \\
\hline
\end{tabular}

Adapted from Nigeria economic fact sheet 2011

From the table above, it is clear that unemployment increased from $21.1 \%$ in 2010 t0 23\% in 2011. Most of the population affected by unemployment are middle age between ages of 15-24 year old. Female has the highest unemployment rate than male with ratio of $24.9 \%$ to $17.7 \%$ and the region with highest rate of unemployment is the northern part of Nigeria especially the north -west follow by the north east National Bureau of Statistics(2011). 
Table 1.3 Key micro economic indicator 2009-2011

\begin{tabular}{|c|c|c|c|c|}
\hline S/NO & Description & 2009 & 2010 & 2011 \\
\hline 1 & Global GDP Growth Rate & $-\overline{0}$ & 5.00 & 4.5 \\
\hline 2 & Real GDP Growth Rate (\%) & $\begin{array}{l}6.9 \\
6 \\
\end{array}$ & 7.87 & $8.2(7.43)$ \\
\hline 3 & Nominal GDP (USD`billion) & $\begin{array}{l}165.7 \\
0\end{array}$ & 194.30 & 226.63 \\
\hline 4 & Nominal Per Capital GDP (USD) & $\begin{array}{l}1,073.8 \\
0\end{array}$ & $1,219.90$ & 1462.1 \\
\hline 5 & Population Growth Rate (\% & $\begin{array}{l}3.2 \\
0 \\
\end{array}$ & 3.20 & 3.2 \\
\hline 6 & Crude Oil Production (mbd) & $\begin{array}{l}2.2 \\
5\end{array}$ & 2.25 & 2.3 \\
\hline 7 & Crude Oil Price (USD) & $\begin{array}{l}60.0 \\
0\end{array}$ & 65.00 & $\begin{array}{l}75 \\
(65)-\text { Exe }\end{array}$ \\
\hline 8 & Monetary Policy Rate (\%) & 6.00 & 6.50 & 8.0 \\
\hline 9 & Total Federally Collected Revenue (N'billion) & $4,332.58$ & $6,362.56$ & $\begin{array}{l}9218.77 \\
(3,809.21)\end{array}$ \\
\hline 10 & Total Oil \& Gas Revenue (N'billion) & $\begin{array}{l}2,999.5 \\
8\end{array}$ & $5,396.19$ & 3046.97 \\
\hline 11 & Total Non-Oil Revenues (N'billion) & $\begin{array}{l}864.6 \\
1\end{array}$ & 966.47 & 762.23 \\
\hline 12 & Capital Expenditure (N’billion) & $\begin{array}{l}562.3 \\
7 \\
\end{array}$ & 912.30 & 1146.76 \\
\hline 13 & Federal Government Expenditure as \% GDP & $\begin{array}{l}10.9 \\
0\end{array}$ & 16.30 & 13.0 \\
\hline 14 & External Debt Stock USD billion & $\begin{array}{l}3.9 \\
5 \\
\end{array}$ & 4.58 & - \\
\hline 15 & External Debt as \% GDP & $\begin{array}{l}2.3 \\
8 \\
\end{array}$ & 2.36 & - \\
\hline 16 & Inflation Rate (\%) & $\begin{array}{l}13.9 \\
0 \\
\end{array}$ & 11.80 & $\begin{array}{l}10.0 \\
(12.4) \\
\end{array}$ \\
\hline 17 & Exchange Rate N/\$ & $\begin{array}{l}148.8 \\
8\end{array}$ & 150.30 & 150.00 \\
\hline 18 & $\begin{array}{l}\text { Foreign Reserves USD million [Number of } \\
\text { Months of Imports] }\end{array}$ & $\begin{array}{ll}42 . & 32 . \\
4 & 3\end{array}$ & $33.3(16.6)$ & $(7.8)(8)$ \\
\hline 19 & Collected Total Tax Revenue as \% of GDP & $\begin{array}{l}5.7 \\
0 \\
\end{array}$ & 6.80 & 9.5 \\
\hline 20 & Fiscal Deficit GDP Ratio (\%) & $\begin{array}{l}3.5 \\
9 \\
\end{array}$ & 3.62 & 2.96 \\
\hline 21 & Unemployment Rate & $\begin{array}{l}19.7 \\
0\end{array}$ & 21.10 & 17.5 \\
\hline 22 & Life Expectancy (Years) & $\begin{array}{l}47.9 \\
0 \\
\end{array}$ & 48.80 & 48.8 \\
\hline 23 & Electricity Generated in Megawatts & $\begin{array}{l}<3,00 \\
0\end{array}$ & $<4,000$ & 10,000 \\
\hline 24 & Contribution of Agric to GDP (\%) & $\begin{array}{l}41.7 \\
0 \\
\end{array}$ & 40.80 & 35.0 \\
\hline 25 & Contribution of manufacturing to GDP(\%) & $\begin{array}{l}4.1 \\
7\end{array}$ & 4.16 & 8.0 \\
\hline 26 & Poverty Incidence $(\%)$ & $\begin{array}{l}54.4 \\
0 \\
\end{array}$ & 54.40 & 54.4 \\
\hline 27 & Manufacturing Capacity Utilization (\%) & $\begin{array}{l}37.0 \\
0 \\
\end{array}$ & 52.00 & 60.0 \\
\hline
\end{tabular}


Role of Governance in Employment Generation in Nigeria

\begin{tabular}{|l|l|l|l|l|}
\hline 28 & All Share Index (ASI) & $20,827.1$ & $24,765.60$ & - \\
& & 7 & & \\
\hline 29 & Market Capitalisation (MC) (N'trillion) & 7.0 & 7.79 & - \\
\hline
\end{tabular}

\section{Source: National Bureau of statistics 2012}

From the table above, global growth fall from 5.0 in 2010 to 4.5 in 2011, population also increased to $3.2 \%$, crude oil price was fluctuating, recurrent expenditure also increased, poverty was at the peak and contributed to the unemployment situation in the country.

\section{Conclusion}

Youth employment in Nigeria is a demand side problem, there are no enough jobs to go round. They key issue is that today's youth are poorly educated, have poor skills that are not in great demand and also no enough jobs been created which led to proliferation of crimes such as the activities of Boko Haram, Niger Delta crises, armed robbery, prostitution and many others.

\section{Recommendations}

1. Anti corruption crusade should attacked the root of corruption: Both the EFCC and Anti corruption commission should look deeply into the root causes of corruption and address it from the beginning which will help greatly in minimizing corruption.

2. Strengthen of existing institutions by appointing decent people to head them, respect their tenure and appoint successors rather than political appointee.

3. Investment in education: Government should invest heavily on education, education that will enable the youth to become self reliance instead of job seekers through skills development and training

4. Infrastructural building that will provide employment to thousand people such as good roads, electricity, provision of portable drinking water etc

5. Criminalization of political thugs through free, fair and credible elections.

6. Selection of leaders based on merit rather than on ascription.

7. Policy makers have a duty to build capable states with the clear purpose of not only expanding economic opportunities but also effectively and efficiently delivering basic services to citizens.

8. Create labour market that work better for the youths.

9. Develop a financial market that support SMEs.

10. Promotion of conducive atmosphere for investment.

\section{Reference}

[1] Nigeria economic fact sheet (2011) United States Embassy in Nigeria retrieved from http/Nigeria. USembassy.gov.

[2] Ribadu, N.(2012) Poor managers for nations woes: constitution not responsible for retrogression, the Sun news paper 12 April 2012 retrieved from http.www.sunnews.com/poor

[3] Danjuma A. (2012) Good governance as panacea to socio-economic crises in Nigeria. IOSR Journal of business and management, volume $2 / 3$ pp 36-40. Retrieved from www.iosriournals.org.

[4] Onno R. (2011) Nigeria's youth: Turning challenge into opportunity retrieved from Nigerian -youth paper.onno.ruhl.pdf

[5] Punch(2012) Youth unemployment6: Why Okonjo- Iweala is wrong, Jully 31 2012. Retrieved from http/www.punchng.com/opinion/youth

[6] NLC(2012)unemploymentcrisis between data and reality Guardian July 122012 retrieved from http/www.ngr.guardiannews.com

[7] Hallary (2012) Failuure of governance in Nigeria. BBC Hausa service, Wednesday 25 April 2012.

[8] NECA(2012)unemploymentcrisisbetweendataand reality Guardian July 122012 retrieved from http/www.ngr.guardiannews.com

[9] National bureau of statistics Annual socio-economic report retrieved from http/www.nigerianstatgovng/uploads/latest release ff063b27de8aa15b35f1a6fb04bf472c658d939.pdf (2011)

[10] Apata T.G.; Apata O.M.; Igbalajobi O.A and Awoniyi S. M. Determinant of rural poverty in Nigeria: Evidence from small holder farmers in south-western, Nigeria. Journal of science and technology education research vol (4) (2010)pp 85-91 http.www.academicjournal.org/JSTER

[11] Sanusi L : Sanusi predicts increase in Nigerian poverty level, Vanguard February 162012 (2012)retrieved from http/www.vanguard.com/2012/sanusipredict increase

[12] Sanusi L. (2012) Falling oil price, threat to Nigerian economy-Sanusi Vanguard August 2,2012, retrieved from http/www.Vanguard.com/2012/08 